\title{
Quality of Life at Resettlement Project in Pahang, Malaysia
}

\author{
Jamalunlaili Abdullah ${ }^{1}$, Nazura Mohamed Sayuti ${ }^{2}$, \\ Afiza Azura Mohamad Arshad ${ }^{2}$, Mohd Ruzed Embong ${ }^{1}$ \\ ${ }^{1}$ Faculty of Architecture, Planning and Surveying, \\ Universiti Teknologi MARA, 40450 Shah Alam, Malaysia \\ ${ }^{2}$ Faculty of Business Management, \\ Universiti Teknologi MARA, Puncak Alam, Malaysia \\ jamal858@salam.uitm.edu.my; bota65@yahoo.com
}

\begin{abstract}
This paper studies the quality of life of Orang Asli (aborigines) who were resettled at Program Bersepadu Daerah Terpencil (PROSDET), Pantos in Kuala Medang, Pahang, Malaysia. The research aims to examine the living conditions of the affected Orang Asli at the resettlement project and to determine possible ways for improving their livelihood and quality of life. The findings from 183 household surveys and physical observations and interviews have disclosed dissatisfactions among Orang Asli for reasons which related to the changes in their traditional livelihood, lifestyle and culture. The paper provides recommendations for ensuring better quality of life in the future resettlement programs for Orang Asli.
\end{abstract}

Keywords: Orang Asli; Quality of Life; Resettlement; PROSDET Pantos

eISSN 2398-4279 @ 2018. The Authors. Published for AMER ABRA cE-Bs by e-International Publishing House, Ltd., UK. This is an open access article under the CC BY-NC-ND license (http://creativecommons.org/licenses/bync-nd/4.0/). Peer-review under responsibility of AMER (Association of Malaysian Environment-Behaviour Researchers), ABRA (Association of Behavioural Researchers on Asians) and cE-Bs (Centre for EnvironmentBehaviour Studies), Faculty of Architecture, Planning \& Surveying, Universiti Teknologi MARA, Malaysia.

DOI: https://doi.org/10.21834/ajqol.v3i10.109 


\subsection{Introduction}

Orang Asli are the aborigines of the Malay Peninsula who are believed to have settled in as early as 11,000 BC (Bellwood, 1997). According to the Aboriginal Peoples Act 1954 (Act 134) under the Aboriginal Peoples Ordinance No 3, 1954, which was amended in 1974, Orang Asli is defined as follows:

i. any of which his father was a member of the ethnic group of indigenous people, who speak the language of Aboriginal and ordinarily follow the way of life of indigenous peoples and traditional Aboriginal beliefs, and includes a descent through the male

ii.any person of any race were adopted by Aboriginal and who was brought up as an Aboriginal , habitually speaks the language of indigenous people, according to the way of life of indigenous peoples and traditional Aboriginal beliefs, and become members of a indigenous peoples; or

iii.children of any union between an Aboriginal woman with a man of another race , provided the child was habitually speaks the language of Aboriginal and Aboriginal beliefs and still be a member of an Aboriginal community .

In Malaysia, Orang Asli represents a minority of Malaysian population, accounting for 149,723 from the total population of 30 million people (JHEOA, 2006 cited by Jamalunlaili, 2015), whom have been living in isolation for many years. They have been deprived of proper living condition to enhance quality of life. Nevertheless, the government of Malaysia has, since independence, allocated millions of dollars to improve their quality of life (QOL) through better living condition. QOL is the general well-being of individuals and societies in such areas as housing, food, education, clothing, transportation, and employment opportunities (Mohd Fauzi \& Nor Aini, 2012).

There have been numerous development projects undertaken by the Malaysian government towards achieving Malaysia 2020 Vision. Indirectly the benefits from the development projects will also be shared with this minority group. Department of Orang Asli Development (JAKOA) through its Socio-Economic Development Division (PSE) is responsible to oversee the well-being and balanced quality of life among the Orang Asli. Infrastructure in villages, mindset change and poverty and education level of Orang Asli has been given attention. Therefore, settlement projects have been introduced to provide a better living condition aiming at improving the life style and education level of this community. Thus PSE continuously administers and develop infrastructure for Orang Asli settlements with the purpose of developing and providing comfort to the Orang Asli.

This paper investigates the quality of life of the resettled Orang Asli as it is one of the government's initiatives to restructure village and to have integrated development of rural areas. It employs socio-economic survey from six affected villages namely Kampung Kuala Suar, Lanai Baru, Perangkap, Tisut, Nyentil and Harong, upstream of Telom River, who had been resettled under Integrated Program for Remote Areas - Program Bersepadu Daerah Terpencil (PROSDET) Pantos at Kuala Medang, Pahang, Malaysia by JAKOA in 2012. The specific objectives of this paper are;

i.to evaluate the socio-economic conditions of Orang Asli at the resettlement area

li.to ascertain the satisfaction level of Orang Asli towards the new resettlement program lii.to determine reasons for dissatisfaction towards the new resettlement area. 
iv.to provide possible rectifications for better quality life style of Orang Asli

\subsection{Literature Review}

The Aboriginal Peoples Act 1954 (Act 134) has provided the provision under S6 and S7 for any state authority to gazette any area on the state land to be declared as Aboriginal Areas or Aboriginal Reserves for the occupancy of aboriginal peoples. In addition, under S8 the state authority may also grant rights of occupancy of any state land for the aboriginal peoples, but only as a tenant at will. Cited from Ismail (2010), settlement areas for aboriginal people in Malaysia covers about 50,563 hectares of land throughout Malaysia. From that area, about 19,7013 hectares are gazetted under the Aboriginal Peoples Act 1954 (Act 134) and another 30,489 hectares were already approved by the State Government as the settlement area but not yet gazetted under Act 134 . On the aspect of ownership, only $0.03 \%$ of the lands were owned individually by the aboriginal people. Most of the lands were occupied without proper registration by this community, which in the case of any land dealings or acquisition, the rights of these aboriginal peoples were being denied.

Aboriginal people are known as very attached to their cultures and lands. These people live in a community and have their administration system led by the hereditary headman. They are using their land use system which differs from one tribe to another. The land usage might be different according to their living area or way of life, but the aboriginal people have traditionally followed the system for a very long time. Although these aboriginal people live a nomadic lifestyle, some have established their living area and stay within the area for generations. After the existence of Aboriginal People Act 1954 (Act 134), many settlement areas for aboriginal people have been gazetted, which become a proper and permanent aboriginal people village.

Some Orang Asli was resettled due to their traditional villages being acquired for various development purposes (Alias et al, 2010). However, most of these people were not happy or satisfied with the acquisition and resettlement by the government. Among the reasons highlighted in that study include encroachment on rights and heritages which affects the cultures, beliefs and heritages of the tribe, inadequate compensation, unfulfilled promises to protect these aboriginal people interests, unsuitable resettlement location, loss of place to practice traditional lifestyle, loss of traditional jobs and skills, integration problems, difficulties in adjusting to new environment and short evacuation notice. Table 1 shows the summary of some land acquisition and resettlement resulting from project development.

Table 1: Some of the Land Acquisition Cases of Traditional Land in Malaysia

Settlement Area

\begin{aligned} & Settlement Area \\ \hline 1 & Kampong Teiji, Ulu Jelai, Pahang Kampong Leryar, Ulu Jelai, \\ 2 & Pahang \\ 3 & Kangai Temir, Lembah Klau, Raub, Pahang \\ 4 & Kampong Bukit Tampoi, Sepang, Selangor (38.477 acres) 1996\end{aligned}


$5 \quad$ Kampung Sayong Pinang, Kampung Pasir Assam and Kampung

Semanggar Dalam (total 53,000 acres)

Source: Anuar Alias, 2010

Resettlement of Orang Asli by the Malaysian government is a strategy to integrate them into mainstream national community and to improve their livelihood. Safety is another main reason of this exercise (Jamalunlaili, 2015). Some argue that health, education and other socio-economic services for Orang Asli can be delivered more effectively (Othman, Lamin, Sihab \& Said , 2012; Rusaslina Idrus, 2011). Regrouping, following the model of in situ development adopted from Federal Land Development Authority (FELDA) allows for saving in infrastructure and development costs while allowing for services to be provided more easily (Ibrahim Ngah, 2010).

Judging from various studies conducted in Malaysia, the resettlements of Orang Asli have brought varied results. Lim (1997) reveals that regrouping exercise of Jakun families in Bukit Serok and Keratung 3 in Pahang was a success due to voluntary participation of Orang Asli. Orang Asli became more confident and earned independent income from permanent agriculture and wage earning as well as better housing and basic facilities. On the other hand, Forum Asia contends that resettlement programs of Orang Asli have led to increased poverty, malnutrition, a higher mortality rate and a general deterioration of the health of villagers. They also have negative impacts to the environment, negating the aim of conservation and initially envisaged (Ab Hadi, Roddin, Razzaq, Mustafa \& Baser, 2013). Jamalunlaili and Mohammad Al-Aiman (2015) find that almost half of the Orang Asli resettled and surveyed in Bukit Lanjan prefer to move out of the new modern settlement despite given comfortable bungalows. Some of the houses were found to be abandoned.

\subsection{Methodology}

This study employs various data collection approaches. This survey adopts both qualitative and quantitative approaches in order to grasp more accurate findings for more informative findings. Several physical observations and interviews were carried out at the the Orang Asli old villages and the settlement area. This was conducted to determine the problem and issues of the area. The site visits involved close physical observation of the affected location on ground and the land use within close proximity on various indicators such as the physical conditions, infrastructure, economic activities and socio-culture. A casual conversation with affected families was carried out to retrieve preliminary responses with regard to the new resettlement area. Discussions with the Heads of the identified villages were executed to reconfirm information assembled at the preliminary study. In addition, Orang Asli was also asked about the current state of resettlement houses, surrounding areas, daily activities, and amenities provided by JAKOA.

Survey questionnaires in this study involved in total of 183 households who were resettled at PROSDET Pantos. Table 2 shows in 2013, JAKOA listed 198 families from 6 villages were given the house at the settlement area. However, the survey revealed only 193 houses were built. 135 (73.8\%) Orang Asli was able to be surveyed and analyzed. They were the Head 
of Households of each family.

Table 2 Classification of Samples at the PROSDET Pantos

\begin{tabular}{lll}
\hline No & Village & Household \\
\hline 1 & Harong & 47 \\
2 & Lanai & 48 \\
3 & Nyentil & 42 \\
4 & Tisut & 14 \\
5 & Perangkap & 38 \\
6 & Suar & 9 \\
\hline & Total & 198 \\
\hline
\end{tabular}

Source: JAKOA 2013

\subsection{Findings and Discussions}

The resettled Orang Asli previously lived at the old settlement villages located upstream of Telom River. They lived in individual houses within their roaming area. Farming and hunting have been their daily activities and source of income. The lands have been cultivated with rubber and fruit trees such as durians and rambutans. At the new settlement area, this Orang Asli is resettled in brick detached houses provided by the government. Besides the houses, the settlement area is also equipped with basic facilities and amenities such as primary school, football field, prayer hall for Muslims, electricity, water and accessibility roads. However, due to insufficient quantity of houses built by JAKOA, a number of Orang Asli continues to stay in their traditional villages. Some occasionally revisit their traditional villages to continue with their traditional economic activities to earn their daily income. Only families with school-going children will stay at the settlement area since the school is located nearby. The affected Orang Asli was aware of the resettlement objectives but reluctant to forgo their traditional houses and lifestyles. They strongly attached to their traditional land which had been in their life for generations. The survey outcome the level of satisfaction of the Orang Asli on the resettlement as depicted in Table 3. The results indicate that 68 out of 135 respondents (50.4\%) were satisfied with the resettlement provided by JAKOA at PROSDET Pantos.

Table 3 Level of Satisfaction on the Resettlement at at PROSDET Pantos

\begin{tabular}{l|ll}
\hline \multicolumn{2}{|l}{ Frequency } & Percentage \\
\hline Yes & 68 & 50.4 \\
\hline No & 61 & 45.2 \\
\hline Not Sure & 6 & 4.4 \\
\hline Total & 135 & 100.0 \\
\hline
\end{tabular}

61 out of 135 respondents were not satisfied with the resettlement due to the reasons portrayed in Table 4. Multiple reasons were given by the respondents where the highest $(21.1 \%)$ of the respondents were dissatisfied with the resettlement provided by JAKOA at 
PROSDET Pantos. They claimed to be unable to cultivate the land due to the unsuitability of the soil for cultivation. The houses do not fit for large families which is rather a norm in Orang Asli community. 19.9\% acknowledged the discomfort of staying at the resettlement house provided by JAKOA. The third reason for dissatisfaction is losing their source of income from farming. Orang Asli claimed to loss income from their daily traditional activities. The new settlement area provides them with no roaming areas. Other reason for dissatisfaction is the non-resemblance and reflection of the culture and heritage of Orang Asli and depriving them of their traditional activities specifically hunting and farming.

This research also reported on the perception of Orang Asli at PROSDET Pantos towards the development project within their vicinity. The findings reveal that $63.3 \%$ of the respondents reflected their hope and aspiration for a better quality of life and ability to secure a better and higher living status derived from any development project. They also have the aspirations for the younger generation to secure a higher level of education besides be given opportunities to get tertiary education. Only a small majority (15.0\%) of the respondents did not harbor any hope or aspiration from development. The research outcome is reported in Table 5.

Table 4 Reasons for dissatisfaction on the new resettlement area

\begin{tabular}{|c|c|c|}
\hline & \multicolumn{2}{|c|}{ Response } \\
\hline & Frequency & Percentage \\
\hline No roaming area & 19 & $11.4 \%$ \\
\hline $\begin{array}{l}\text { No suitable land to } \\
\text { garden/farm }\end{array}$ & 35 & $21.1 \%$ \\
\hline Loss of income from crops & 31 & $18.7 \%$ \\
\hline $\begin{array}{l}\text { New resettlement area } \\
\text { lack of } \quad \text { traditional } \\
\text { characteristics }\end{array}$ & $\begin{array}{c}22 \\
33\end{array}$ & $\begin{array}{l}13.3 \% \\
19.9 \%\end{array}$ \\
\hline $\begin{array}{l}\text { New resettlement house is } \\
\text { not suitable for extended } \\
\text { family }\end{array}$ & 26 & $15.7 \%$ \\
\hline $\begin{array}{l}\text { Inadequate } \\
\text { amenities }\end{array}$ & & \\
\hline
\end{tabular}

Table 5: Aspiration of Orang Asli towards Development

\begin{tabular}{|l|l|l|l|}
\hline & N & Percent & Percentage \\
\hline Pursue higher education & 66 & $25.0 \%$ & $55.0 \%$ \\
\hline Work in the public sector & 36 & $13.6 \%$ & $30.0 \%$ \\
\hline Work in the private sector & 19 & $7.2 \%$ & $15.8 \%$ \\
\hline Run own business & 14 & $5.3 \%$ & $11.7 \%$ \\
\hline Continue family tradition - farmer & 35 & $13.3 \%$ & $29.2 \%$ \\
\hline Not expecting anything & 18 & $6.8 \%$ & $15.0 \%$ \\
\hline Secure and better standard of living & 76 & $28.8 \%$ & $63.3 \%$ \\
\hline & $\mathbf{2 6 4}$ & $\mathbf{1 0 0 . 0 \%}$ & $\mathbf{2 2 0 . 0 \%}$ \\
\hline
\end{tabular}

\subsection{Conclusion}

Orang Asli who is resettled at $\mathrm{Kg}$ Pantos, Pahang mostly are unhappy with the new living 
conditions existing provided by JAKOA. This indicates the resettlement project fails to provide quality of life to the resettles. Findings indicate this settlement area was initiated without considering the traditional lifestyle of the Orang Asli who still insists on practising their norms. Quality of life of Orang Asli may be enhanced by providing settlement area which is suitable for simple farming activities to occupy them with their habitual activities. Topsoil should be laid out on the current barren and rocky soil to allow villagers to plant vegetables or rear livestock. Employment opportunities in agriculture sector may likely to attract the Orang Asli to stay permanently in the new settlement

The new settlement area does not provide any roaming area for this Orang Asli. This is due to the distance between the new settlement area and the old villages are quite far which requires long boat ride. Changing their mind set may become a challenge for JAKOA but JAKOA should continuously educate this Orang Asli with new and potential economic activities to enhance their wellbeing. This can be achieved by providing hands on training to build up new skills as a method to boost education level among Orang Asli. Gradually the change of mind set is anticipated and this Orang Asli may no longer shy away from the majority population.

The houses provided at settlement area $\mathrm{Kg}$ Pantos are not suitable for extended families, leading to overcrowding in the houses. Despite given detached houses and amenities such as school, futsal court and a mosque, many of Orang Asli still long for their old villages. The settlement area can still be improved by making more comfortable modern settlements without ignoring the traditional features of Orang Asli's houses.

\section{Acknowledgement}

We are greatly indebted to Tenaga Nasional Berhad (TNB) and MASMED UiTM for trusting our capabilities as the researchers and providing us with the financial support throughout the study.

\section{References}

Ab.Hadi, M. Y., Roddin, R., Razzaq, A. R. A., Mustafa, M. Z., \& Baser, J. A. (2013). Poverty Eradication through Vocational Education (Tourism) among Indigenous People Communities in Malaysia: Pro-poor Tourism Approach (PPT). Procedia - Social and Behavioral Sciences, 93, 1840-1844. doi:10.1016/j.sbspro.2013.10.127

Alias, A. and Daud M.N (2011), SAKA: Adequate Compensations for Orang Asli Native Land, Batu Pahat, Malaysia: Universiti Tun Hussein Onn

Government of Malaysia (2010), Aboriginal people Act 1954 (Act 134), Pub. L. No Act 134 (1954), Kuala Lumpur: Government Printer

Jabatan Kemajuan Orang Asli Malaysia (2015), Portal Rasmi Jabatan Kemajuan Orang Asli, Retrieved from http://www.jakoa.gov.my/

Jalong, T. (2013). Universal Periodic Review of Malaysia (2013) by Indigenous Peoples Network of Malaysia (JOAS) (Review). Penampang, Sabah: Indigenous Peoples Network of Malaysia. Retrieved from http://www.upr- 
info.org/IMG/pdf/js7_upr17_mys_e.pdf

Jamalunlaili Abdullah and Mohammad Al-Aiman Borkhan (2015), Orang Asli Resettlement in Urban Environment at Bukit Lanjan, Selangor, Malaysia. Proceeding AcE-Bs 2015 Tehran, Asian Conference on Human Behavior Studies 21st February 2015.

Karim, H. A., and Hashim, A. H. (2012). The Effect of a Resettlement Scheme on the Social-Cultural Changes of the Temuan Community. Procedia - Social and Behavioral Sciences, 42, 362-373. doi:10.1016/j.sbspro.2012.04.200

Mohd Fauzi Mohd Harun \& Nor Aini Hj Idris (2012), The Quality of Life of Malaysian Aborigines: Measured with a Weighted Quality of Life Index for Orang Asli, Akademika 82(1) 2012: 65-69

Othman, C. N., Lamin, R. A. C., Farooqui, M., Sihab, N., \& Said, S. M. (2012). Lifestyle Related Diseases amongst Orang Asli in Peninsular Malaysia-Case Study. Procedia - Social and Behavioral Sciences, 36, 383-392. doi:10.1016/j.sbspro.2012.03.042

Persatuan Aliran Kesedaraan Negara (Aliran). (2010, November 4). Bantahan dasar pemberimilikan tanah Orang Asli. ALIRAN. Retrieved from http://aliran.com/civil-society-voices/memo-bantahan-dasar-pemberimilikan-tanahorang-asli/

World Commission on Dams (WCD) (2000), Dams and Development: a new framework for decision 